\title{
Lateral
}

Journal of the Cultural Studies Association

\section{Review of Iconoclasm: The Breaking and Making of Images edited by Rachel F. Stapleton and Antonio Viselli (McGill-Queen University Press)}

\author{
by $\underline{\text { Charles Athanasopoulos }}$ Book Reviews, Issue 9.2 (Fall 2020)
}

\begin{abstract}
Using an eclectic mix of artifacts (e.g. romance novels, historical sites, religious texts, literary texts), Iconoclasm highlights the cyclical nature of iconoclastic gestures and iconolatry. For the authors in this edited collection, iconoclasts reenergize iconophiles' investments in a particular object through its shattering. In taking a Nietzschean perspective on destruction, they also gesture toward the ways in which iconoclastic acts contain the seeds of a new form of idol worship. Highlighting what they call the "Taussigian principle," this text compels the reader to consider whether iconoclasm unwittingly reproduces the dialectical relationships it attempts to escape.
\end{abstract}

KEYWORDS culture, Frantz Fanon, Nietzsche, religion

Iconoclasm: The Breaking and Making of Images. Edited by Rachel F. Stapleton and Antonio Viselli. Montreal \& Kingston, Canada: McGill-Queen University Press, 2019. Pp. 215. (paper) ISBN 780773557376

Rachel F. Stapleton and Antonio Viselli's edited collection of essays takes readers on a journey through various examples of iconoclasm and its relationship to the creation and/or veneration of icons. In the introduction, they explain that the common thread between this eclectic mix of essays is the way each author highlights the reciprocal nature of iconolatry and iconoclasm. Put another way, Iconoclasm builds on the scholarly works of Michael Taussig, WJT Mitchell, and Bruno Latour, all three of whom who have attempted to demonstrate how "the act of destroying the sacred unintentionally bestows iconic status on the desecrated object" and how an obsession with transgression itself becomes a new form of idol worship (1). For them, the iconoclastic gesture also contains the seeds of creation, producing new images out of the ruins of what they have shattered. Thus, the utility of this text is not limited to religious scholars but more broadly to those also interested in the relationship between the breaking and making of institutions, philosophies, and dogmas.

In chapter one, Michael Taussig declares "Iconoclasm is written into the icon. Taboos are meant to be broken" (22). Taussig offers the example of the obelisk that exists in France at the Place of Concord: each act of iconoclasm that unfolds at this site- the beheading of French monarch Louis XVI, the theft of Egyptian monarchical icons for European government, the de-facing of the obelisk with a pink condom by ACT UP-ultimately served to make this iconic site relevant in new ways (29). Indeed, Taussig performatively 
demonstrates many of the claims made in the outset of the book through this keen example.

After framing the major argument of the book in the introduction and Michael Taussig's "Iconoclasm Dictionary" in chapter one, Stapleton and Viselli organize this edited collection of essays according to major keywords that are inextricable from the operation of icons. The keywords that organize the book are "religion," "pop art," "nation," and "sexy," and each thematic section opens with a brief definition of the keyword and its importance to the overall project. Then, each keyword is followed by two chapters that wrestle with that concept as it relates to icons.

In chapter two, Christopher Van Ginhoven Rey theorizes iconoclasm through "religion" by meditating on how the shattering of Christ's physical form pushes his followers toward his spirit, faith, and the creation of a larger Christian social body (43). Following this, Beth Saunders pushes readers to consider photography itself as a kind of religious ritual centered on producing icons in which the polaroid becomes an object of devotion through a discussion of Marian apparitions (76).

The next keyword "pop art" is introduced by Natalie Pendergast's comic book-style representation of an attempt at defining the term. In the fourth chapter, Emily Hoffman centers Paul Newman, an actor known for playing anti-hero characters and for being anticelebrity culture. Hoffman cleverly highlights how Newman's rejection of popular culture became a unique branding technique that paradoxically increased his iconic status (85). In chapter five, Brendon Wocke uses the artist Banksy as an example of how the everyday person can become an iconoclast through the use of their freedom of expression in the fifth chapter. However, Wocke argues that Banksy's queering of images of England's Queen Elizabeth works to re-energize investment in the Crown and makes the artist himself paradoxically iconic because of his iconoclastic gestures (115-116).

Shifting to a consideration of "nation," T. Shotzko's chapter six examines how shows like Mad Men create advertisements for their show by riffing on the symbolic images of people falling from buildings during the terrorist attacks on 9/11 (130). For these producers, their symbolic adaptations of those images represent the fall of Western "man" while also suggesting that the show is meant to show us western man's ability to find his place again through the story of Don Draper. In the seventh chapter, Adam Swann reads Milton's History of Britain through the lens of what Taussig calls Nietzschean iconoclasm. Swann argues that Milton's text, much like Nietzsche's Twilight of the Ido/s, highlights the cyclical nature of history and thinks of destruction as a creative process that can rid us of the idols of nationalism in favor of something beyond like the over-Man. (148-149).

Centering the final keyword "sexy" in chapter eight, Angela Toscano describes romance novels as shattering realism through the creation of clichés that offer us a happily-everafter. Thus, we move away from reality toward a veneration of these new mythic/iconic conceptions (188). The final chapter in the edited collection, written by Helen Hester, argues that pornography as a genre is not simply driven by an interest in genitalia but a broader interest in the desecration of other cultural forms.

This collection is an important contribution to the field of cultural studies because of the way it implicates iconoclastic gestures within systems of power against the notion that iconoclasm is synonymous with liberation. The line between icon creation and destruction becomes increasingly muddled as we traverse these various themes (religion, pop art, nation, sexy), calling into question what you thought you knew about icons. If anything 
could further strengthen this text, perhaps it would be a discussion of iconoclasm in context of the toppling of racist monuments and abolitionist rhetoric(s) more broadly. Despite this, I believe that this book can be read in tandem with growing literature at the intersection of iconoclasm, anti-Blackness, multiculturalism, liberal sovereignty, and more. For example, how might Hester's analysis concerning the vampirism of pornography relate to debates amongst Black feminist scholars concerning the nuances of Black women's experiences in the industry and the relationship between desecration, shame, and Blackness? How might we extend Shotzko's argument concerning the fear of Western man's fall to consider the anxieties of the white middle-class that drives the "Make America Great Again" movement? In particular, I wonder what it would look like to put this text in conversation with scholarship in Black studies that is concerned with how iconoclastic gestures such as the shattering the Black Codes of the Jim Crow era is only replaced with new violent policies in a neoliberal era. If Taussig demonstrates how the line between tearing down an icon and building a new one has become blurred, then one might apply this logic to argue that the iconoclastic civil rights/Black power movements of the mid-to-late 1960s has resulted in the erasure of anti-Black violence through the worship of new iconic legislation such as the Civil Rights Act of 1964.

\section{Author Information}

\section{Charles Athanasopoulos}

Charles Athanasopoulos is a PhD student at the University of Pittsburgh. His research interests include Black rhetorical studies, Fanonian thought, the Black Lives Matter movement, racial iconography, and media studies.

View all of Charles Athanasopoulos's articles.

\section{Article details}

Charles Athanasopoulos, "Review of 'Iconoclasm: The Breaking and Making of Images' edited by Rachel F Stapleton and Antonio Viselli (McGill-Queen University Press)," Lateral 9.2 (2020).

\section{https://doi.org/10.25158/L9.2.9}

This content is licensed under a Creative Commons Attribution-NonCommercial 4.0 International License. Copyright is retained by authors.

Lateral is the peer-reviewed, open access journal of the Cultural Studies Association. 
